\title{
Onion as a Pest Control Intercrop in Organic Cabbage (Brassica oleracea) Production System in Ghana
}

\author{
P. K. Baidoo (Corresponding author) \\ Department of Theoretical and Applied Biology \\ Kwame Nkrumah University of Science and Technology, Kumasi, Ghana \\ E-mail: pkbaidoo2002@yahoo.com \\ M. B. Mochiah \\ Entomology Section, Crop Research Institute \\ PO Box 3785, Kwadaso, Kumasi, Ghana \\ K. Apusiga \\ Department of Theoretical and Applied Biology \\ Kwame Nkrumah University of Science and Technology, Kumasi, Ghana
}

Received: November 26, $2011 \quad$ Accepted: December 24, $2011 \quad$ Published: February 1, 2012

doi:10.5539/sar.v1n1p36

URL: http://dx.doi.org/10.5539/sar.v1n1p36

\begin{abstract}
The use of chemical insecticides in the control of insect pests has left in its wake resistance of some pests to some of the conventional insecticides. Alternative methods of managing pests such as cultural control have to be employed to reduce pest infestation of crops. Onion was used in an intercrop as a non host crop to manage the pests of cabbage. The experiment was conducted in a Randomized Complete Block Design with four treatments; sole cabbage (T1), 2 rows of cabbage to 1 row of onion (T2), 3 rows of cabbage to 1 row of onion (T3) and 4 rows of cabbage to 1 row of onion (T4), each of which was replicated three times. Data were collected on pests' numbers, plant height, damaged leaves at harvest, canopy spread, number of damaged heads and fresh weight. Significantly fewer Bemisia tabaci, Hellula undalis and Brevicoryne brassicae infested the intercropped plants than the sole crop. However, intercropping cabbage with onion did not significantly reduce Plutella xylostella population on cabbage. Number of damaged heads, fresh weight and damaged leaves were significantly different $(\mathrm{P}<0.05)$.
\end{abstract}

Keywords: Brevicoryne brassicae, Cabbage, Onion, Plutella xylostella, Intercropping

\section{Introduction}

Cabbage, Brassica oleracea L. is an exotic leafy vegetable grown in many tropical areas in Africa. It is a biennial potherb, but is usually cultivated as an annual. It grows best in mild to cool climates (Cabbage, 2010 Encylopaedia Britannica). Structurally, cabbage has a short thickened stem surrounded by a series of overlapping expanded leaves which form a compact head (Rice et al., 1986). Cabbage is often used in stews, boiled in soups and also eaten fresh as an ingredient of salads (Van der Vossen and Seif, 2004). According to Norman (1992), cabbage is nutritionally a rich leafy vegetable. Per $100 \mathrm{~g}$ of raw cabbage, the nutritional values are: 21 cal energy, $1.2 \mathrm{~g}$ protein, vitamins and some minerals such as potassium, phosphorus, magnesium and sodium.

The nutritional value and succulent nature of cabbage has attracted many insect pests which feed on it. The insect pest complex associated with cabbage include aphids, Aphis brassicae, diamondback moth, Plutella xylostella, the cabbage webworm Hellula undalis, the cabbage looper, Trichoplusia ni (Chalfant et al., 1979; Shelton et al.,1982; Mochiah et al., 2011), and the white fly , Bemisia tabaci. These pests damage the cabbage head by making holes in the leaves, destroying the growing buds and tunnel into mature heads. The feeding activities of these pests reduce the quality of cabbage heads and subsequently its market value, leading to financial loss to the farmer. 
The destructive nature of cabbage pests necessitates the application of control measures to minimize the effects of these pests. Chemical insecticides have been used against insect pests in vegetable crop production. However, several problems are associated with the use of chemical insecticides. These include the development of resistance, environmental contamination, and increased health hazards to applicators and dangers to consumers of high toxic residues. The rapid increase in the numbers of these pests necessitates the application of high doses of pesticides (Kim et al., 2001). The use of insecticides in vegetable production is on the increase despite the problems associated with their use. Insecticide resistance is the underlying cause of insecticide dependency among farmers. This has resulted in farmers using more powerful insecticides to be able to control these pests. Roush and Tabashnik (1990) stated that the use of insecticides has resulted in the evolution of resistance in more than 440 insect species and mites worldwide. Perez et al. (2000) assessed the insecticide resistance to several insecticides of five insect pests including P. xylostella and Spodoptera exigua attacking field and vegetable crops in Nicaragua and observed that $P$. xylostella showed resistance to cypermethrin, deltamethrin, thiocyclam and methamidophos.

The concept of intercropping involves the cultivation of two or more crops simultaneously on the same field. The rationale behind intercropping is that the different crops planted are not likely to be attacked by the same pests. The commonest goal of intercropping is to produce a greater yield on a given piece of land, making use of resources that would otherwise not be utilized by a single crop. Intercropping reduces pest population because of the diversity of crops grown. When other crops are present in the field pests movements are hindered. According to Sullivan (2003), if susceptible plants are separated by non- host plants that can act as a physical barrier to the pest, the susceptible plant will suffer less damage.

The use of synthetic chemical insecticides have been effective in controlling pests, but the continuous use pose harmful effects like residual contamination of the produce, environmental pollution as well as pest resistance. There is therefore the need to seek alternative methods of managing pests. Intercropping, in combination with organic farming provide an alternative means of managing pests. The study therefore assessed the role of intercropping and organic farming in the management of major pests of cabbage.

\section{Materials and Methods}

\subsection{Study area}

The experiment was conducted on an experimental farm of the Department of Theoretical and Applied Biology, Kwame Nkrumah University of Science and Technology, Kumasi from December 2010 to April 2011. The area falls within the forest zone of Ghana and is characterized by relatively high annual rainfall of about $730 \mathrm{~mm}$ and annual minimum and maximum temperatures of $21.5{ }^{\circ} \mathrm{C}$ and $32.1{ }^{\circ} \mathrm{C}$ respectively (Addo-Fordjour et al., 2007). The soil type is sandy loam and the topsoil is about $0.3 \mathrm{~m}$ deep.

Cabbage and onion seeds were obtained from an Agrochemical shop. They were nursed separately in the Greenhouse until ready for transplanting. The farming system used in the study was strictly organic. This system excluded the use of insecticides, growth hormones and any other synthetic chemical used in modern farming systems. No fertilizer was applied throughout the growth of the plants.

\subsection{Experimental design}

Twelve experimental beds each measuring $4.5 \mathrm{~m} \times 1.5 \mathrm{~m}$ were raised, each separated by $0.5 \mathrm{~m}$ alley. The experiment was conducted in a Randomized Complete Block Design (RCBD) with four treatments each of which was replicated three times. The treatments were sole cabbage (T1); 2 rows of cabbage intercropped with 1 row of onion (T2); 3 rows of cabbage intercropped with 1 row of onion (T3) and 4 rows of cabbage intercropped with 1 row of onion (T4). Cabbage and onion seedling were transplanted 3 weeks after germination. The square planting distance was used. Distance between the cabbage plants, both within and between rows was $0.45 \mathrm{~m}$ and the row intercropping was used. There were 30 cabbage plants on each bed, both on the sole cabbage and any of the intercropping options. Management of weeds was done periodically by manually uprooting them.

\subsection{Data collection}

Data were collected on the following parameters on cabbage: pests' species and numbers, canopy spread, plant height, number of damaged heads at harvest, numbers of damaged leaves at harvest and fresh weight of cabbage heads. At each sampling for insect pests, five cabbage plants were randomly sampled from the inner row. The leaves of the sampled plants were carefully examined for insect pests. Insects collected were placed separately in Kilner jars sent to the laboratory, counted and their numbers recorded. 


\subsubsection{Canopy spread}

Measurement of canopy spread was done at the time of harvest with a metre rule. The spread of canopy was measured as the horizontal distance from one end of the plant to the other i.e. the two most outspread and directly opposite leaves of the plant.

\subsubsection{Plant height}

Plant height was measured from the soil surface to the apex of the plant. The highest point reached by the plant was recorded as the height of the plant.

\subsubsection{Number of damaged leaves and heads}

At harvest the number of damaged leaves per cabbage plant were counted and recorded. Damaged leaves were removed from the rosette, one after the other until no damaged leaf was found. The numbers of damaged heads that were not able to form marketable heads were counted, recorded and the means calculated. Five cabbage heads were randomly sampled from each bed and weighed on a top pan balance. This was done for each treatment and the mean for each was calculated and recorded.

\subsection{Data analysis}

Data collected were analyzed using the general Linear Model (GLM) procedure of SAS (SAS, Institute, 2005). Number of insects count were $\log (\mathrm{x}+1)$ transformed. Comparison of the means was done using the Student Neuman-Keul's (SNK) test. Significant difference was set at $\mathrm{P} \leq 0.05$.

\section{Results}

\subsection{Insect pests encountered on cabbage}

During the growth of the cabbage plant a number of insect pests were identified attacking the plant. These include the diamondback moth Plutella xylostella (L), the cabbage aphid, Brevicoryne brassicae (L.), the cabbage webworm, Hellula undalis (F.), the whitefly, Bemisia tabaci (Genn.) and the cabbage looper, Trichoplusia ni (Hübner). These pests attacked the plant at different growth stages of the plant.

P. xylostella was observed on cabbage at 4 weeks after transplanting (WAT) and remained on the plant till harvest. P. xylostella numbers were largest on the sole cabbage plots (T1) which were the control plots and least on T4 plots (i.e. 4 rows of cabbage to 1 row of onion). However, the numbers of $P$. xylostella on the intercropped plots and the sole cabbage plots were not significantly different $(\mathrm{P}=0.063)$ (Table 1). B. brassicae was observed at 2 WAT. Their numbers ranged from a mean of 34 on sole cabbage to 17.3 on 4 rows of cabbage to 1 row of onion (T4); the difference was significant $(\mathrm{P}=0.004)$. However, $B$. brassicae numbers on sole cabbage (T1) and two rows of cabbage to one row of onion (T2) were not significantly different (Table 1).

Bemisia tabaci was observed at 6WAT. Their numbers decreased consistently from the sole cabbage, T1 to four rows of cabbage to one row of onion, T4. Even though generally low numbers were recorded on all plots, many more were recorded on the sole cabbage plots than the intercropped plot. Intercropping cabbage with onion significantly reduced and not reduce the numbers of this pest on cabbage $(\mathrm{P}=0.002)$. Cabbage webworm $H$. undalis appeared on the plant at $6 \mathrm{WAT}$, which was relatively late in the growth of the plant. They were most abundant on the sole cabbage plots and completely absent on 4 rows of cabbage to 1 row of onion (T4).Significant differences in numbers existed among the intercropped plants and the sole cabbage plants.

The cabbage looper, $T$. $n i$ was also observed on the plant at 6 WAT, with the largest number infesting the sole cabbage, whilst the T4 plots were least infested. However, the observed differences were not significant $(\mathrm{P}=$ $0.164)$. Thus intercropping did not reduce the population of this pest on cabbage.

\subsection{Effects of intercropping system on growth, damage by pests and yield of cabbage}

The effects of intercropping on growth parameters and damage by pests are shown in Table 2. Plant height ranged from a mean of $28.73 \mathrm{~cm}$ on four rows of cabbage and one row of onion (T 4) to $30.09 \mathrm{~cm}$ on the sole cabbage plots (T1). It was observed that intercropping did not significantly affect plant height $(\mathrm{P}=0.620)$. Mean canopy spread on the plots did not differ significantly $(\mathrm{P}=0.992)$. As a consequence of heavy pests attack, the mean number of damaged leaves at harvest was largest on the sole cabbage plots (T1) but least on 4 rows of cabbage to 1 row of onion (T4) $(\mathrm{P}=.021)$. There was however, no significant differences in leaf damage among the intercropped plants (Table 2). Mean number of damaged heads was least on 4 rows of cabbage to 1 row of onion (T4) and largest on 2 rows of cabbage to 2 row of onion (T2). Mean fresh weight of cabbage heads were significantly heavier on the intercropped plots than on the sole cabbage plots (Table 2). 


\section{Discussion}

Cabbage is an important leafy vegetable which forms an important component of the diets of many African countries. However increased production of this crop is being hindered by pests' attack. The stage of growth of the plant at which pests attack the crop is very significant to the survival of the crop. Cabbage plants that were infested early could not completely survive the attack and as a consequence produced smaller and lighter heads. Even though intercropped cabbages recorded lower numbers of P. xylostella, these were not significantly different from that recorded on the sole cabbage. This finding lends support to the report by Lingappa et al. (2006), who stated that intercropping is not reliable in controlling diamondback moth. Asare-Bediako et al. (2010), however, stated that intercropping cabbage with non-host crops such as onion and tomato significantly reduced $P$. xylostella numbers on cabbage. In their study however, the chemical insecticide Dursban (chloropyrifos) was used to spray the plants whilst in the current study the farming practice was purely organic where no insecticide was used.

Aphids attack the tender leaves of cabbage plants and secrete honeydew which accumulates on leaves leading to growth of sooty mould which affected the yield of cabbage (Blackman \& Eastop, 2000). Thus the reduction of $B$. brassicae numbers on the intercropped plants subsequently led to a reduction in damaged leaves. The significantly lower numbers of $B$. brassicae on the intercropped plants was attributed to the confusing olfactory and visual cues offered by onion which reduced their ability to disperse. Sankar et al. (2007) stated that intercropping cabbage with garlic and onion significantly reduced the population of aphids on cabbage. Similarly, Said and Itulya (2003) indicated that the odour from onion is able to repel $P$. xylostella from settling on cabbage when in an intercrop. Garlic and onion produce a pungent alliaceous compound, allyl-epropyl-disulphide, which is responsible for its pest repellent attribute.

Intercropping also reduces pests attack because the non host crop act as physical barriers to the movement of insect pests (Sheehan, 1986). Studies conducted by Bach and Tabashnik (1990) in Hawaii found that cabbage interplanted with tomato contained lower numbers of $P$. xylostella larvae and higher levels of parasitism compared with monoculture cabbage. High temperatures and low rainfall promote the increase in numbers of $P$. xylostella and B. brevicoryne. However, during the months of February and March, there were unusually heavy rains which were an important mortality factor washing off the eggs, larvae and nymphs from the leaves. This phenomenon was thoroughly studied by and reported by Kobori and Amano (2003) who observed that 1 hour of stimulated rain resulted in $95.3 \%$ drop off of $1^{\text {st }}$ instar, $72 \%$ of $2^{\text {nd }}$ instar, $60.7 \% 3^{\text {rd }}$ instar and $42.7 \% 4^{\text {th }}$ instar of P. xylostella. This was an indication that heavy rainfall reported during those months resulted in heavy mortality. Warm and dry weather are particularly favourable for rapid development of cabbage pest such as aphids (Horna et al., 2006) and P. xylostella.

In cabbage one important factor that determines the marketability of the crop is the extent of damage to the head. Cabbage heads that are heavily infested by pests are less attractive to buyers. The intercropped cabbage recorded significantly lower numbers of damaged leaves. However, with the exception of T4 which recorded fewer damaged leaves, the other intercropped plots recorded numbers of damaged leaves which were not significantly different from the sole cabbage. In the study, the highest marketable yield was recorded on T4 and least on T1 (sole cabbage). In some instances, intercropping results in loss of weight in vegetable plantings (Theunissen et al., 1995). However, in the current study, intercropping resulted in increased weight in cabbage. According to Cerruti et al. (2002), from an economic point of view any increase in quality due to intercropping must be sufficient to compensate for lower number of heads or intercropping systems may only be practicable in systems where quality is of greatest importance. In the current study it was observed that as a result of reduction of pests numbers on the intercropped cabbage an increase in yield of $11.03 \%$ to $50.1 \%$ were recorded compared with the sole cabbage. Lotz et al. (1997) however, reported a reduced yield of cabbage of $15-24 \%$ when intercropped with clover due to competition between the two crops. It therefore means that non-host crop in an intercropping must be carefully selected in order not to compete with the main crop for essential nutrients.

\section{Conclusion}

The results of this study indicated that onion can be used as an intercrop in the management of cabbage pests. The fact that reduction in pests' numbers and significant increase in yield were achieved without the use of insecticides was an indication that when adopted by the small to medium scale African farmer it would improve yield and increase the incomes of farmers. In the current study, it was observed that in an intercrop, the secondary crop needs not occupy much area of the available land to produce the desired effects. Hence intercropping every four rows of cabbage with one row of onion will serve as an effective pest management strategy and effective land use. 


\section{Acknowledgements}

The authors are grateful to Dr. E. D. J. Belford for his advice and helping to bring the manuscript to this form. This study was supported by a collaborative project between the Department of Theoretical and Applied Biology, Kwame Nkrumah University of Science and Technology, Kumasi and Crops Research Institute (CRI) of the Council for Scientific and Industrial Research (CSIR).

\section{References}

Addo-Fordjour, P., Yeboah-Gyan, K., Lawson B. W. L., \& Akanwariwiak, W. G. (2007). Diversity and distribution of ferns on the campus of Kwame Nkrumah University of Science and Technology, Kumasi, Ghana. Journal of Science and Technology, 27(1), 35-44.

Asare-Bediako, E., Addo-Quaye, A. A., \& Mohammed, A. (2010). Control of diamondback moth (Plutella xylostella) on cabbage (Brassica oleracea var. capitata) using intercropping with non host crops. American Journal of Food Technology, 5, 269-274. http://dx.doi.org/10.3923/ajft.2010.269.274

Bach, C. E., \& Tabashnik, B. E. (1990). Effect of non-host neighbours on population densities and parasitism rates of the diamondback moth (Lepidoptera: Plutellidae). Environmental Entomology, 19, 987-994.

Blackman, R. L., \& Eastop, V. F. (2000). Aphids on the world's crops. An identification and information guide. In: predominance of parthenogenetic reproduction in Aphis gosypii populations on summer crops and weeds in Greece. Bulletin of Insectology, 62, 15-20.

Cabbage. (2010). Encyclopaedia Britannica. Ultimate Reference Suite, Chicago.

Cerruti, L., Hooks, R. R., \& Marshall, W. J. (2002). Lepidopteran pest populations and crop yields in row intercropped broccoli. Agricultural and Forest Entomology, 4(2), 117-125. http://dx.doi.org/10.1046/j.1461-9563.2002.00129.x

Chalfant, R. B., Denton, W. H., Schuster, D. J., \& Workman, R. B. (1979). Management of cabbage caterpillars in Florida and Georgia by using visual damage thresholds. Journal of Economic Entomology, 72, 411-413.

Horna, D., Melinda, S., \& Falck-Zepeda, J. (2006). Assessing the potential economic impact of genetically modified crops in Ghana: tomato garden egg, cabbage and cassava. PBS Report, October 2006, Brief No1-2.

Kim, J. J., Lee, M. H., Yoon, C., \& Kim, H. (2001). Control of cotton aphid and greenhouse whitefly with a fungal pathogen. Entomologica Experimenta et Applicata, 27, 1-5.

Kobori, Y., \& Amano, H. (2003). Effect of rainfall on a population of diamondback moth Plutella xylostella (Lepidoptera: Plutellidae). Japanese Applied Entomology and Zoology, 38(2), 249-253. http://dx.doi.org/10.1303/aez.2003.249

Lingappa, S., Basavanagoud, K., Kulkuarni, K. A., Roopa, S., \&. Kambrekar, D. N. (2006). Threat to vegetable production by diamondback moth and its management strategies. Vol. 1, Springer, Netherlands, 357-396.

Lotz, L. A. P., Groeneveld, R. M. W., Theunissen, J., \& Van Den Broek, R. C. F. M. (1997). Yield losses of white cabbage caused by the competition with clovers grown as cover crop. Netherland Journal of Agricultural Science, 45, 393-405.

Mochiah. M. B., Baidoo, P. K., \& Owusu-Akyaw, M. (2011) Influence of different nutrient applications on insect populations and damage to cabbage. Journal of Applied Biosciences, 38, 2564-2572.

Norman, J. C. (1992). Tropical Vegetable Crops. In: Elms Court Ilfracombe ,Stockwell, H. (Ed) Devon Publishers, U.K.

Perez, C. J., Alvarado, P., Narvaez, C., Miranda, F., Hernandez, L., Vanegas, H., Hrusk, A., \& Shelton, A. M. (2000). Assessment of insecticide resistance in five insect pests attacking field and vegetable crops in Nicaragua. Journal of Economic Entomology, 93(6), 1779-1787. http://dx.doi.org/10.1603/0022-0493-93.6.1779

Rice, R. P., Rice, L. W., \& Tindall, H. D. (1986). Fruit and Vegetable Production in Africa. MacMillan Press, London. Pp 175-176.

Roush, R. T., \& Tabashnik, B. E. (1990). Pesticide resistance in arthropods. New York: Chapman and Hall.

Said, M., \& Itulya F. M. (2003). Intercropping and nitrogen management effects of diamondback moth and yields of collards in the highlands of Kenya. African Crop Science Journal, 2, 35-42.

SAS Institute. (2005). Statistical Analytical Systems SAS/STAT user's guide version 9(1) Cary NC: SAS Institute Inc. 
Sankar, P. K., Rahman, M. M., \& Das, B. C. (2007). Effect of intercro pping of mustard with onion and garlic on aphid population and yield. Journal of Biological Science, 15, 35-40.

Sheehan, W. (1986). Response of specialist and naturalist natural enemies to agroecosystem diversification. A selective review. Environmental Entomology, 15, 456-461.

Shelton, A. M., Andaloro, J. T., \& Bernard, J. (1982). Effects of cabbage looper, imported cabbage worm and diamondback moth on fresh market and processing cabbage. Journal of Economic Entomology, 75, 742-745.

Sullivan, P. (2003). Intercropping principles and practice. Agronomy Systems Guide. Appropriate Technology Transfer for, Rural Areas (ATTRA) <http://attar.Ncat.og/attar-PDF/intercrop.pdf $>$.Assessed 14 October 2010.

Theunessen, J., Booij, C. J. H., \& Lotz, L. A. P. (1995). Effects of intercropping white cabbage with clovers on pest infestation and yield. Entomologia Experimentalis et Applicata, 74, 7-16. http://dx.doi.org/10.1111/j.1570-7458.1995.tb01869.x

Van der Vossen, H. A. M., \& Seif, A. A. (2004). Brassica oleracea (L.)(Headed cabbage) Record from Protabase. Grubben, G. J. H. \& Denton, O. A. (Eds.). Plant Resources of Tropical Africa. Wageningen, Netherlands.

Table 1. Effects of intercropping on the mean numbers (SE) of pests of cabbage

\begin{tabular}{cccccc}
\hline Cropping System & P.xylostella & B. brassicae & B. tabaci & H. undalis & T. ni \\
\hline $\begin{array}{c}\text { Sole cabbage } \\
\text { 2 rows of cabbage to 1 } \\
\text { row of onion }\end{array}$ & $21.74^{\mathrm{a}} \pm 3.75$ & $34.0^{\mathrm{a}} \pm 2.10$ & $6.73^{\mathrm{a}} \pm 1.70$ & $1.40^{\mathrm{a}} \pm 0.52$ & $0.80^{\mathrm{a}} \pm 0.39$ \\
$\begin{array}{c}\text { 3 rows of cabbage to 1 } \\
\text { row of onion }\end{array}$ & $15.07^{\mathrm{a}} \pm 2.95$ & $21.3^{\mathrm{b}} \pm 3.20$ & $2.60^{\mathrm{bc}} \pm 0.64$ & $0.20^{\mathrm{b}} \pm 0.11$ & $0.27^{\mathrm{a}} \pm 0.15$ \\
$\begin{array}{c}\text { 4 rows of cabbage to 1 } \\
\text { row of onion }\end{array}$ & $10.20^{\mathrm{a}} \pm 2.49$ & $17.3^{\mathrm{b}} \pm 4.10$ & $0.60^{\mathrm{c}} \pm 0.19$ & $0.00^{\mathrm{b}} \pm 0.00$ & $0.07^{\mathrm{a}} \pm 0.01$ \\
$\quad$ P-value & 0.063 & 0.004 & 0.002 & 0.005 & 0.165 \\
\hline
\end{tabular}

Within columns means with the same letter are not significantly different $\mathrm{P}>0.05$.

Table 2. Effects of intercropping systems on growth, damage and yield of cabbage

\begin{tabular}{cccccc}
\hline Cropping System & $\begin{array}{c}\text { Plant height } \\
(\mathrm{cm})(\mathrm{SE})\end{array}$ & $\begin{array}{c}\text { Damaged heads } \\
\text { at harvest (SE) }\end{array}$ & $\begin{array}{c}\text { Damaged } \\
\text { leaves (SE) }\end{array}$ & $\begin{array}{c}\text { Weight of } \\
\text { cabbage }(\mathrm{kg}) \\
(\mathrm{SE})\end{array}$ & $\begin{array}{c}\text { Canopy spread } \\
(\mathrm{cm})(\mathrm{SE})\end{array}$ \\
\hline $\begin{array}{c}\text { Sole cabbage } \\
\text { rows of cabbage } \\
\text { to } 1 \text { row of onion }\end{array}$ & $29.09^{\mathrm{a}} \pm 0.96$ & $2.67^{\mathrm{a}} \pm 0.33$ & $16.33^{\mathrm{a}} \pm 1.7$ & $1.05^{\mathrm{a}} \pm 0.035$ & $22.95^{\mathrm{a}} \pm 1.60$ \\
$\begin{array}{c}\text { 3 rows of cabbage } \\
\text { to } 1 \text { row of onion }\end{array}$ & $29.04^{\mathrm{a}} \pm 0.51$ & $3.67^{\mathrm{ab}} \pm 0.67$ & $13.00^{\mathrm{ab}} \pm 1.0$ & $1.21^{\mathrm{a}} \pm 0.028$ & $22.90^{\mathrm{a}} \pm 1.70$ \\
$\begin{array}{c}\text { 4 rows of cabbage } \\
\text { to 1 row of onion } \\
\text { P-value }\end{array}$ & $\begin{array}{c}28.73^{\mathrm{a}} \pm 0.94 \\
0.620\end{array}$ & $1.33^{\mathrm{b}} \pm 0.00$ & $11.33^{\mathrm{ab}} \pm 0.67$ & $1.24^{\mathrm{a}} \pm 0.105$ & $23.10^{\mathrm{a}} \pm 1.67$ \\
\hline
\end{tabular}

Within columns means with the same letter are not significantly different $\mathrm{P}>0.05$. 